\title{
ОКИСНЮВАЛЬНА МОДИФІКАЦІЯ БІЛКІВ У ЩУРІВ РІЗНОГО ВІКУ ЗА УМОВ ГОСТРОГО ОТРУЄННЯ ТОКСИНАМИ БЛІДОЇ ПОГАНКИ
}

Вступ. В останні роки вітчизняні та зарубіжні вчені отримали численні дані про важливу роль окиснювальної модифрікації білків у розвитку багатьох захворювань. Відомо, що надходження в організм токсичних сполук, зокрема токсинів блідої поганки, різко пригнічує антиоксидантну систему та підвищує вміст продуктів пероксидного окиснення ліпідів і білків у печінці й нирках.

Мета дослідження - вивчити динаміку показників окиснювальної модифрікації білків у щурів різного віку, уражених отрутою блідої поганки, в різні періоди експерименту.

Методи дослідження. У всіх дослідних групах моделювали отруєння шляхом одноразового внутрішньочеревного введення екстракту блідої поганки, отриманого за методом H. Wieland (85 мг/кг маси тіла). Евтаназію проводили під тіопентал-натрієвим наркозом через 6, 24 та 72 год після отруєння. Окиснювальну модифрікацію білків у сироватці крові досліджували за методом І. Ф. Мещишена.

Результати й обговорення. Досліджено вплив токсинів блідої поганки Amanita phalloides на показники окиснювальної модифрікації білків у щурів різних вікових періодів. Прогресування патологічного процесу в печінці та виснаження компенсаторних можливостей у тварин з гострим отруєнням блідою поганкою призводили до активації процесів вільнорадикального окиснення білків і зростання в динаміці показників окиснювальної модифрікації білків. Максимально виражені зміни спостерігали в 6- та 18-місячних щурів через 24 год після інтоксикації.

Висновки. Встановлено, що прогресування патологічного процесу в печінці та виснаження компенсаторних можливостей внаслідок отруєння токсинами блідої поганки призводять до зростання в динаміці показників окиснювальної модифрікації білків. Це можна розглядати як один із ранніх маркерів ушкодження органів та тканин, у тому числі й гепатоцитів, а також як надійний і ранній провісник розвитку патології, пов'язаної з оксидативним стресом.

КЛЮЧОВІ СЛОВА: бліда поганка; отруєння; окиснювальна модифікація білків; вікові особливості отруєння.

ВСТУП. Найбільш небезпечними справедливо вважають отруєння грибами гепатонефротоксичної дії (аманітальні гриби, до яких належать бліда поганка (БП) та її різновиди). За даними K. Olson [1], смертність, зумовлена отруєннями грибами гепатонефротоксичної дії, становить від 10 до 65 \% і залежить насамперед від своєчасності звернення за медичною допомогою.

Висока токсичність БП зумовлена наявністю в ній двох основних груп токсинів: 1) швидкодіючих - фралотоксинів (фралоїдин, фралоїн, профралін, фралідин тощо) і 2) повільнодіючих - аматоксинів (a-, b-, g-, е-аманітини, аманін та деякі інші). Аманітини належать до найбільш токсичних речовин у світі. Смертельною їх дозою вва(С) І. П. Кузьмак, Є. Б. Дмухальська, С. Р. Підручна, Т. Я. Ярошенко, І. Я. Криницька, М. І. Куліцька, 2017. жають 0,1 мг/кг. Одна шапка БП у середньому містить 10-15 мг аманітинів [2, 3].

В основі токсичної дії аматоксинів лежить порушення внутрішньоклітинного синтезу білка за рахунок блокади РНК-полімерази. Це призводить до повної дезінтеграції синтетичних процесів у клітині (насамперед у гепатоцитах) i, зрештою, до ії̈ загибелі [4-7].

Відомо, що надходження в організм токсичних сполук різко пригнічує антиоксидантну систему та підвищує вміст продуктів пероксидного окиснення ліпідів і білків у печінці й нирках.

Окиснення білкових молекул під дією активних фрорм кисню, що утворюються в процесі метаболізму та зумовлюють не лише пероксидацію ліпідів, але й окиснювальну модифікацію білків (ОМБ), призводить до незворотного ушкодження мембранних структур, порушення їх 
проникності й загибелі клітин. In vitro показано, що продукти вільнорадикального окиснення білків спричиняють окиснювальне ураження ДНК. Нагромадження окисненого білка може бути раннім критерієм ушкодження тканин активними фоомами кисню і при деяких патологічних станах досягає 50-70 \% усього клітинного білка. Патогенетична роль продуктів ОМБ зумовлена їх геномо- та цитотоксичністю, спроможністю викликати загибель клітин за типом апоптозу або некрозу [8].

Таким чином, одним із важливих процесів для підтримки гомеостазу та корекції інтоксикаційних явищ в організмі $є$ система пероксидного окиснення білків.

Проте літературні дані щодо інтенсивності процесів пероксидації білків у клітинах печінки за умов аманіта-сралоїдинової інтоксикації відсутні.

Мета дослідження - вивчити процеси ОМБ в уражених отрутою блідої поганки щурів різного віку в різні періоди експерименту.

МЕТОДИ ДОСЛІДЖЕННЯ. Дослідження проводили на білих щурах-самцях, яких утримували на стандартному раціоні віварію. В експерименті використовували тварин трьох вікових періодів: 3-місячних (період статевого дозрівання; молоді), 6-місячних (період статевої зрілості; дорослі) та 18-24-місячних (період старості; старі) [9].

Отруювали тварин шляхом одноразового внутрішньочеревного введення їм екстракту БП, отриманого за методом H. Wieland [10], у дозі 85 мг/кг маси тіла.

Евтаназію щурів проводили шляхом декапітації під тіопенталовим наркозом через 6, 24 та 72 год після отруєння з подальшим забором крові.

Усі маніпуляції з експериментальними тваринами проводили відповідно до Загальних етичних принципів експериментів на тваринах, ухвалених на Першому національному конгресі з біоетики (Київ, 2000) та узгоджених з положеннями Європейської конвенції про захист хребетних тварин, що використовуються для дослідних та інших наукових цілей (Страсбург, 1986).

Окиснювальну модифрікацію білків у сироватці крові досліджували за методом І. Ф. Мещишена [11], який базується на тому, що кінцеві продукти вільнорадикального окиснення білків можуть кількісно реагувати з 2,4-динітрофренілгідразином з утворенням 2,4-динітрофренілгідразонів, що мають характерний спектр поглинання. Альдегідо- і кетонопохідні нейтрального характеру реєстрували при 370 нм, а основного характеру - при 430 нм.

Визначали, відповідно, альдегіддинітрофренілгідразони і кетондинітрофренілгідразони, які характеризують у разі спонтанної ОМБ ступінь окиснювальної деструкції білкової молекули, а при індукованій ОМБ свідчать про виснаження резервно-адаптаційних можливостей організму [11].

Отриманий цифровий матеріал піддавали статистичному аналізу з використанням t-критерію Стьюдента [12], обробку результатів виконували у відділі системних статистичних досліджень Тернопільського державного медичного університету імені І. Я. Горбачевського в програмному пакеті Statsoft STATISTICA.

РЕЗУЛЬТАТИ Й ОБГОВОРЕННЯ. АкТИВація процесів вільнорадикального окиснення призводила до дії активних фрорм кисню і токсичних продуктів метаболізму на білкові компоненти мембран та інші білки організму, що викликало їх деградацію і зміни у структурі.

Результати проведених досліджень (табл.) свідчать про те, що вплив отрути блідої поганки призводив до збільшення рівня окиснювальномодифікованих білків: вміст альдегід- і кетондинітрофенілгідразонів як нейтрального, так і ос-

Таблиця - Динаміка вмісту альдегідо- та кетонопохідних нейтрального (ОМБ $\left.{ }_{370}\right)$ й основного (ОМБ ${ }_{430}$ ) характеру (моль/г білка) в плазмі крові щурів різного віку

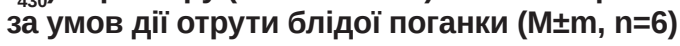

\begin{tabular}{|c|c|c|c|c|c|}
\hline \multirow{3}{*}{$\begin{array}{c}\text { Вік тварин, } \\
\text { міс. }\end{array}$} & \multirow{3}{*}{ Показник } & \multicolumn{4}{|c|}{ Група тварин } \\
\hline & & \multirow{2}{*}{ контроль } & \multicolumn{3}{|c|}{ уражені БП, термін після отруєння, год } \\
\hline & & & 6 & 24 & 72 \\
\hline \multirow[t]{2}{*}{3} & $\mathrm{OMB}_{370}$ & $0,77 \pm 0,02$ & $0,89 \pm 0,01^{*}$ & $0,98 \pm 0,04^{*}$ & $0,94 \pm 0,02 *$ \\
\hline & $\mathrm{OME}_{430}$ & $0,50 \pm 0,01$ & $0,57 \pm 0,05^{*}$ & $0,62 \pm 0,06^{*}$ & $0,54 \pm 0,03^{*}$ \\
\hline \multirow[t]{2}{*}{6} & $\mathrm{OMB}_{370}$ & $0,79 \pm 0,04$ & $1,76 \pm 0,01^{*}$ & $1,93 \pm 0,01^{*}$ & $1,82 \pm 0,02^{*}$ \\
\hline & $\mathrm{OMB}_{430}$ & $0,61 \pm 0,05$ & $1,34 \pm 0,03^{*}$ & $1,59 \pm 0,01^{*}$ & $1,47 \pm 0,15^{\star}$ \\
\hline 18 & $\mathrm{OMB}_{430}$ & $0,72 \pm 0,02$ & $1,46 \pm 0,03^{\star \# \infty}$ & $1,8 \pm 0,04^{\star \# \infty}$ & $1,64 \pm 0,02^{\star \# \infty}$ \\
\hline
\end{tabular}

Примітки:

1. * - відмінності достовірні порівняно з тваринами контрольної групи $\left(p_{1}<0,001\right)$

2. \# - відмінності достовірні між 18- та 3-місячними тваринами $\left(\mathrm{p}_{2}<0,01\right)$

3. ${ }^{\infty}$ - відмінності достовірні між 18- та 6-місячними тваринами $\left(p_{3}<0,01\right)$. 
новного характеру в гепатоцитах дослідних груп лабораторних щурів був статистично достовірно вищим порівняно з контролем.

Крім того, інтенсивність ОМБ у контрольних тварин різних вікових періодів суттєво відрізнялася. У 18-місячних щурів показники ОМБ ${ }_{370}$ перевищували аналогічні результати 3-місячних тварин на $27 \%$, а 6-місячних - на $24 \%$. Концентрація похідних основного характеру перевищувала відповідні показники на 44 та $18 \%$.

Отримані нами дані збігаються з результатами інших дослідників $[13,14]$ і вказують, 3 одного боку, на підвищення чутливості білків до окиснювальної модифрікації в процесі старіння, а з іншого - на зниження швидкості їх деградації шляхом протеолізу.

Виражених змін зазнавали також показники ОМБ в отруєних блідою поганкою тварин різного віку. Зростання альдегідо- і кетонопохідних білків нейтрального характеру відмічено вже через 6 год після отруєння у всіх вікових групах, однак максимально виражених змін ОМБ зазнали 6- та 18-місячні щури через 24 год експерименту. Вміст альдегідо- і кетонопохідних білків нейтрального характеру $\left(\mathrm{OMБ}_{\text {зол }}\right)$ у плазмі крові 3- та 6-місячних тварин збільшився, порівняно з інтактними щурами, у 2,4 і 2,6 раза $(p<0,01)$ відповідно, тоді як вміст альдегідо- та кетонопохідних білків основного характеру $\left(\mathrm{OMБ}_{430}\right)$ - у 2,6 i 2,5 раза $(\mathrm{p}<0,05)$ відповідно порівняно з контролем. Через 72 год

\section{СПИСОК ЛІТЕРАТУРИ}

1. Olson K. Poisoning and drug overdose. - New York: Applton and Lange, 1999. - P. 156-157.

2. Mas A. Mushrooms, amatoxins and the liver / A. Mas // J. Hepatol. - 2005. - № 42. - P. 166-169.

3. Acute Liver Failure Caused by Amanita phalloides Poisoning / L. Santi, C. Maggioli, M. Mastroroberto [et al.] // International Journal of Hepatology. - 2012. https://www.hindawi.com/journals/ijh/2012/487480/

4. Amanita phalloides poisoning: reassessment of prognostic factors and indications for emergency liver transplantation / L. Escudié, C. Francoz, J. P. Vinel [et al.] // Journal of Hepatology. - 2007. - 46, № 3. P. 466-473.

5. Poisonous mushrooms; a review of the most common intoxications / A. D. L. Lima, R. Costa Fortes, M. R. C. Garbi Novaes [et al.] // Nutr. Hosp. - 2012. - 27, № 2. - P. 402-408.

6. Molecular characterization and inhibition of amanitin uptake into human hepatocytes / K. Letschert, H. Faulstich, D. Keller, D. Keppler // Toxicol. Sci. - 2006. P. 140-149. спостерігали деяке зниження концентрації показників ОМБ порівняно з 24 год, проте рівня інтактних тварин досягнуто не було.

Однією з причин зростання концентрації ОМБ у плазмі крові старих тварин, отруєних токсинами блідої поганки, може бути зниження активності системи антиоксидантного захисту, особливо фрерментів першого ряду, які здатні знешкоджувати активні фрорми кисню, що і $є$ безпосередньою причиною пероксидного окиснення білків. А також за умов старіння в організмі підсилюються процеси ОМБ із накопиченням утворених продуктів за рахунок зниження активності протеасом, що беруть участь у селективному руйнуванні модифрікованих білків.

ВИСНОВКИ. Аналіз динаміки змін продуктів пероксидного окиснення білків у щурів різного віку за умов гострого отруєння токсинами блідої поганки, отриманих у результаті експериментального дослідження, є відображенням ступеня окиснювального ураження клітин та резервноадаптаційних можливостей організму. Підвищення вмісту продуктів ОМБ у плазмі крові щурів у динаміці можна розглядати як один із ранніх маркерів ушкодження органів та тканин, у тому числі й гепатоцитів, а також як надійний і ранній провісник розвитку патології, пов'язаної з оксидативним стресом.

Отримані результати вимагають подальшого вивчення.

7. Bensaude O. Inhibiting eukaryotic transcription: Which compound to choose? / O. Bensaude // How to evaluate its activity? Transcription. - 2011. - 2 (3). - P. 103 Bensaude 108. doi:10.4161/trns.2.3.16172.

8. Berlett B. S. Protein Oxidation in Aging, Disease, and Oxidative Stress / B. S. Berlett, E. R. Stadtman / The Journal of Biological Chemistry. - 1997. - 272, № 33. - P. 20313-20316. http://dx.doi.org/10.1074/ jbc.272.33.20313

9. Савченков М. Ф. Методические вопросы исследований по возрастной токсикологии / М. Ф. Савченков // Гигиена и санитария. - 1979. - № 11. C. $58-61$.

10. Wieland H. Uber die Giftstoffe des Knollenblatterpilzes. VI. Amanitin, das Hauptgift des Knollenblatterpilzes / H Wieland, R. Hallermayer // Liebig's Ann. Chem. - 1941. - 548. - S. 1-18.

11. Мещишен І. Ф. Метод визначення окиснювальної модифрікації білків плазми (сироватки) крові / І. Ф. Мещишен // Буковин. мед. вісн. - 1998. - 2, № 1. C. 156-158. 
12. Лакин Г. Ф. Биометрия / Г. Ф. Лакин. - М. : Высшая школа, 1990. - 352 с.

13. Rodney Levine L. Oxidative modification of proteins during aging/ Rodney L. Levine, Earl R. Stadtman // Experimental Gerontology. - 2001. - 36 (9). - P. 14951502. http://dx.doi.org/10.1016/S0531-5565(01)00135-8
14. Age-Related Changes in Protein Oxidation and Proteolysis in Mammalian Cells / T. Grune, R. Shringarpure, N. Sitte, K. Davies / J. Gerontol. A Biol. Sci. Med. Sci. - 2001 - 56 (11). - P. B459-B467. https://doi. org/10.1093/gerona/56.11.B459

\section{REFERENCES}

1. Olson, K. (1999). Poisoning and drug overdose. New York: Applton and Lange.

2. Mas, A. (2005). Mushrooms, amatoxins and the liver. J. Hepatol., 42, 166-169.

3. Santi, L., \& Maggioli, C. (2012). Acute liver failure caused by amanita phalloides poisoning. International Journal of Hepatology. Retrieved from https://www. hindawi.com/journals/ijh/2012/487480/

4. Escudié, L., Francoz, C., \& Vinel, J. (2007). Amanita phalloides poisoning: reassessment of prognostic factors and indications for emergency liver transplantation. Journal of Hepatology, 46 (3), 466-473.

5. Lima A.D.L., Costa Fortes, R., \& Garbi Novaes, M.R.C. (2012). Poisonous mushrooms; a review of the most common intoxications. Nutricion Hospitalaria., 27 (2), 402-408. doi:10.3305/nh.2012.27.2.5328

6. Letschert, K., Faulstich, H., Keller, D. (2006). Molecular characterization and inhibition of amanitin uptake into human hepatocytes. Toxicol. Sci., 91 (1), 140-149. doi: 10.1093/toxsci/kfj141

7. Bensaude, O. (2011). Inhibiting eukaryotic transcription: Which compound to choose? How to evaluate its activity? Transcription, 2 (3), 103-108. doi:10.4161/ trns.2.3.16172.

8. Berlett, B.S., \& Stadtman, E.R. (1997). Protein oxidation in aging, disease, and oxidative stress. The
Journal of Biological Chemistry, 272 (33), 20313-20316. doi:10.1074/jbc.272.33.20313

9. Savchenkov, M.F. (1979) Metodicheskie voprosy issledovaniy po vozrastnoi toksykologii [Methodological issues of research on age-related toxicology]. Gigiena $i$ sanitariia - Hygiene and Sanitation, 11, 58-61 [in Russian]

10. Wieland, H., Hallermayer, R. (1941). Uber die Giftstoffe des Knollenblatterpilzes. VI. Amanitin, das Hauptgift des Knollenblatterpilzes. Liebig's Ann. Chem., 548, 1-18.

11. Meshchyshen, I.F. (1998) Metod vyznachennia okysniuvalnoi modyfikatsii bilkiv plazmy (syrovatky) krovi [Method of determining the oxidative modification of plasma proteins (serum) blood]. Bukovynskyi medychnyi visnyk - Bukovynian Medical Journal, 2 (1), 156-158 [in Ukrainian].

12. Lakin, G.F. (1990). Biometriia [Biometrics]. Moscow: Vysshaia shkola [in Russian].

13. Levine, R.L., Stadtman, E.R. (2001). Oxidative modification of proteins during aging. Experimental Gerontology, 36 (9), 1495-1502. doi: 10.1016/S05315565(01)00135-8

14. Grune, T., Shringarpure, R., \& Sitte N. (2001). Age-Related Changes in Protein Oxidation and Proteolysis in Mammalian Cells. J. Gerontol. A Biol. Sci. Med. Sci., 56 (11), B459-B467. doi:10.1093/gerona/56.11.B459

И. П. Кузьмак, Е. Б. Дмухальская, С. Р. Пидручная, Т. Я. Ярошенко, И. Я. Криницкая, М. И. Кулицкая ТЕРНОПОЛЬСКИЙ ГОСУДАРСТВЕННЫЙ МЕДИЦИНСКИЙ УНИВЕРСИТЕТ ИМЕНИ И. Я. ГОРБАЧЕВСКОГО

\section{ОКИСЛИТЕЛЬНАЯ МОДИФИКАЦИЯ БЕЛКОВ У КРЫС РАЗНОГО ВОЗРАСТА В УСЛОВИЯХ ОСТРОГО ОТРАВЛЕНИЯ ТОКСИНАМИ БЛЕДНОЙ ПОГАНКИ}

\section{Резюме}

Вступление. В последние годы отечественные и зарубежные ученые получили многочисленные данные о важной роли окислительной модификации белков в развитии многих заболеваний. Известно, что поступление в организм токсических соединений, в частности токсинов бледной поганки, резко подавляет антиоксидантную систему и повышает содержание продуктов перекисного окисления липидов и белков в печени и почках.

Цель исследования - изучить динамику показателей окислительной модификации белков у крыс разного возраста, пораженных ядом бледной поганки, в разные периоды эксперимента. 
Методы исследования. Во всех опытных группах моделировали отравление путем однократного внутрибрюшного введения экстракта бледной поганки, полученного по методу H. Wieland (85 мг/кг массы тела). Эвтаназию проводили под тиопентал-натриевым наркозом через 6, 24 и 72 ч после отравления. Окислительную модификацию белков в сыворотке крови исследовали по методу И. Ф. Мещишена.

Результаты и обсуждение. Исследовано влияние токсинов бледной поганки Amanita phalloides на показатели окислительной модифрикации белков у крыс разных возрастных периодов. Прогрессирование патологического процесса в печени и истощение компенсаторных возможностей у животных с острым отравлением бледной поганкой приводили к активации процессов свободнорадикального окисления белков и возрастанию в динамике показателей окислительной модификации белков. Максимально выраженные изменения наблюдали в 6- и 18-месячных крыс через 24 ч после интоксикации.

Выводы. Установлено, что прогрессирование патологического процесса в печени и истощение компенсаторных возможностей вследствие отравления токсинами бледной поганки приводят к возрастанию в динамике показателей окислительной модификации белков. Это можно рассматривать как один из ранних маркеров повреждения органов и тканей, в том числе и гепатоцитов, а также как надежный и ранний предвестник развития патологии, связанной с оксидативным стрессом.

КЛЮЧЕВЫЕ СЛОВА: бледная поганка; отравление; окислительная модификация белков; возрастные особенности отравления.

I. P. Kuzmak, Ye. B. Dmukhalska, S. R. Pydruchna, T. Ya. Yaroshenko, I. Ya. Krynytska, M. I. Kulitska I. HORBACHEVSKY TERNOPIL STATE MEDICAL UNIVERSITY

\section{PROTEIN OXIDATIVE MODIFICATION IN WHITE RATS OF DIFFERENT AGES UNDER ACUTE POISONING BY AMANITA PHALLOIDES TOXINS}

\section{Summary}

Introduction. In recent years, scientific articles of domestic and foreign scientists obtained numerical data on the important role of oxidative modification of proteins in the development of many diseases. It is known that entering the organism of toxic compounds, including toxins of Amanita phalloides, sharply oppress antioxidant system increases the contents of peroxidation products lipids and proteins in liver, kidneys.

The aim of the study - to examine the dynamics of oxidative modification of proteins in rats of different ages affected by poison Amanita phalloides toxins in different periods of the experiment.

Methods of the research. In all experimental groups poisoning was modeled by single intraperitoneal administration Amanita phalloides extract obtained by the method of $\mathrm{H}$. Wieland ( $85 \mathrm{mg} / \mathrm{kg}$ body weight). Euthanasia was performed under sodium thiopental anesthesia at 6, 24 and 72 hours after poisoning. Oxidative modification of proteins in blood serum was investigated by Meschyshen method.

Results and Discussion. Protein oxidative modification indices in all age groups rats on the model of toxic injury by Amanita phalloides toxins were investigated. It was found out that the progression of the pathological process in the liver and the depletion of the compensatory capacity in animals with acute poisoning by Amanita phalloides leads to the activation of free radical oxidation of proteins and cause the increasing of protein oxidative modification indices. The most pronounced changes occur in 6- and 18- month rats in 24 hours after intoxication.

Conclusions. It was defined, that the progression of the pathological process in the liver and the depletion of the compensatory capacity as a result of poisoning by toxins of Amanita phalloides cause the increasing of protein oxidative modification indices. It can be considered as one of the earliest markers of damage to organs and tissues including hepatocytes and reliable early predictor of the development and pathology related oxidative stress.

KEY WORDS: Amanita phalloides; poisoning; protein oxidative modification; age-related features of poisoning.

Отримано 08.02.17

Адреса для листування: І. П. Кузьмак, Тернопільський державний медичний університет імені І. Я. Горбачевського, м. Волі, 1, Тернопіль, 46001, Україна, e-mail: iryna_kuzmak@yahoo.com. 